\title{
Die Geschäftsführung
}

im

\section{klassischen römischen Recht}

\author{
Von
}

Dr. Mario Morelli

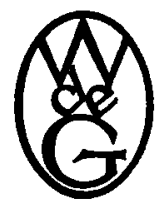

Berlin und Leipzig I 935

W a 1 t e r d e G r u y t e r \& $\quad$ C o. vormals G. J. Göschen'sche Verlagshandlung - J. Guttentag, Verlagsbuchhandlung - Georg Reimer - Karl J. Trübner - Veit \& Comp. 
Archiv-Nr. 244935

Druck von Walter de Gruyter \& Co., Berlin W 10

Printed in Germany 